\title{
THE ARTISTIC CONNECTIONS OF THE ROMANESQUE WALL PAINTINGS IN KOSTOL'ANY POD TRIBEČOM (SLOVAKIA)
}

\section{KRISZTINA ILKO}

UDC: $75.052 .033 \cdot 4(437.6)$

Preliminary communication

Manuscript received: 02. 11. 2015.

Revised manuscript accepted: 10. 03 .2016.

DOI: 10.1484/J.HAM.5.111349
K. Ilko

University of Cambridge

(Department of History of Art)

Pembroke College

Trumpington Street

CB2 1RF Cambridge, United Kingdom

The aim of this paper is to research the Romanesque wall paintings of the church in Kostolany pod Tribecom (Slovakia) in the context of their artistic exchange. I will focus on three images: the Annunciation, the Nativity, and the Magi on the road. All of these pictures represent unusual iconographical types, which cannot be explained by contemporary local artistic tradition. I will argue that the master of the murals was inspired by certain image types originating in the late antique and Carolingian periods, and preserved primarily in the Mediterranean. The mode of transmission of these pictures would have been small, mobile artefacts, most of all ivories and manuscript illuminations, but also artistic manuals. Observing these possibilities I will try to further understand the genesis of these enigmatic wall paintings.

Keywords: medieval iconography, wall painting, Romanesque art, artistic exchange, Annunciation, Visitation, Nativity, journey of the Magi, adoration of the Magi, comparative iconography

The wall paintings of the nave of a small rural church in Kostolany pod Tribečom, which belonged to the northern part of the Hungarian kingdom and is now in Slovakia, does not just represent one of the earliest well-preserved fresco cycles from the Hungarian kingdom, but possesses a unique iconography. In my study I will focus on three images: the Annunciation, the Nativity, and the Magi on the road. All of these pictures represent an iconographical type which was already unfashionable after the first millennium, which offers the opportunity to research their artistic connections in a longue durée.

In the Annunciation picture beside the Virgin Mary and the angel a third person, a young maiden, is also depicted. Two other maidens are represented in the Visitation scene. The Nativity with the spectacular, oval-shaped bed of the Virgin, the bathing scene, the resting Joseph, and another mysterious person in the left edge of the picture also represents a special version of the image type. But the most striking part of the interior decoration is the cycle of Magi. The unusually detailed scenes depict the Three Wise Men not as kings, but rather as enigmatic and exotic eastern travellers. All of these pictures refer to certain archetypes and suggest that to understand the meaning of these images we first have to research their artistic genesis.

Until now the previous scholarship analysed their iconography only to determine their date rather than trying to observe the roots of this peculiar iconography and in what possible ways it reached the Hungarian kingdom. All of the highlighted pictures are without proper analogies in their period and place, which cannot be explained entirely by the significant loss of their contemporary artistic material. Therefore the aim of my study is to observe the artistic connections of these wall paintings mainly through late antique and Carolingian models. How did these image types arrive at this church and through what possible mediating material? I believe that by analysing thoroughly these obscure, archaic pictures we can shed light on the methods of artistic exchange between the Mediterranean world and east-central Europe.

\section{DRAWING THE CONTEXT OF THE WALL PAINTINGS}

The small town Kostolany pod Tribečom is located at the foot of Tribeč Mountain, which belonged to the Hungarian kingdom during the middle ages and nowadays is situated in western Slovakia. On the hill of this isolated settlement can be found the church of St George (fig. 1), which was built in the eleventh century. ${ }^{1}$ The core of the building has been preserved: it includes the quadratic apse that joins to the rectangular single nave. The primary structure of the building was extended in the second quarter of the thirteenth century when a second nave with a tower was added to the church, lengthening it in the western direction. ${ }^{2}$ We have to emphasize how very fortunate it is that the murals of the

${ }^{1}$ This date of the church building should be handled with care, since we have no written documents about the beginning of the parish and the building itself is lacking any specific form which could date it with greater precision. Previous research dated the church from the tenth until the thirteenth century. I base my opinion on the earliest archaeological finds from the cemetery, namely the rich burial assamblage of the grave 78/06 that includes the coin (denarius) of Ulrich I (1012-1033, 1034) struck after 1012. More information and a picture about this coin can be found: J. HUNKA, Numizmatický a historický význam mincí objavených pri výskume Kostola sv. Juraja, in Monumentorum tutela 21, 2009, p. 67, about the burial found in 2006: P. BAXA - P. BISTÁK, Prvé výsledky revízneho výskumu cintorína pri Kostolane sv. Juraja v Kostolanoch pod Tribečom, in: Ibidem p. 61. Also, a half-denarius from 1025-1038 of Stephen I of Hungary was found; both of these coins suggest that the church was already in use in the first part of the 11th century. J. HUNKA, Idem p. 68. The simple structure of the building fits very well for this date. The first preserved relevant charter mentions the village as Costelan which refers to the fact that there was already a church there, since kostol in Slavic languages means church. P. SÖRÖS, Az elenyészett benczés apátságok, Budapest, 1912, (A pannonhalmi Szent-Benedek rend története, 12) p. 408.

${ }^{2}$ They opened a door on the southern wall of the new nave, which exists up to now. The details of this door can help us to date this next building period of the church. L. ŠÁŠKY, Predrománsky kostolv Kostolanoch pod Tribečom, in Monumentorum tutela 2, 1967, p. 86-89. 


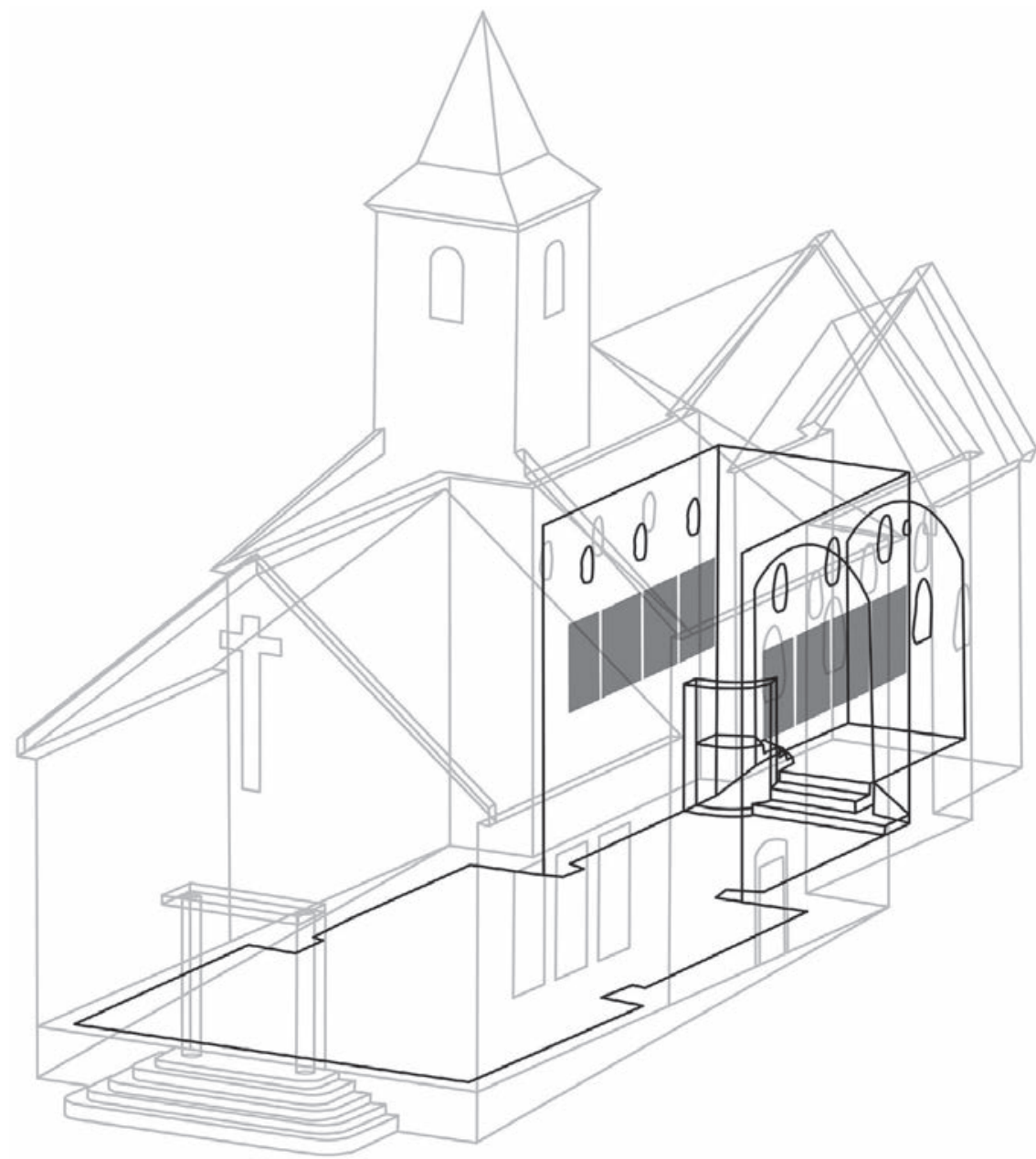

Fig. 1. Kostolany pod Tribečom, St George Church, image: Tamás Szabados - Attila Schulc. by the Slovakian conservator, Pavel Fodor. 5 The quality of the work of Fodor was substandard. He did not just strengthen the contours of the paintings, but worked with minium-based materials which darkened with time. This process made the murals as stiff and rustic as they seem today, and significantly enhanced their monochrome impression. The most recent, still on-going restoration by Marián Keleši aims to deliver the murals from this robust repainting. ${ }^{6}$ However, since we will not be able to study the paintings in their original quality and colours, I have been using the archival photographs from the documentation of the observation of the wall paintings in the 1960's to get as close to the originals as possible. ${ }^{7}$

The sensational discovery brought to light the first painting layer of the church, which was preserved on the greatest part of the southern and northern walls of the nave and depicts an epic Biblical cycle, and with fragments in the apse with the remains of a Maiestas Domini. ${ }^{8}$ The scenes in the nave are ordered into three registers: the two upper levels with narrative scenes and prophet or apostle busts in medallions in the lowest register. The upper level probably contained an Old Testament cycle, however, not much was preserved from it beside a few pairs of legs. 9 The middle register of the south wall contains a Nativity cycle in far better condition: after a devotional scene the Annunciation, the Visitation, and the Birth of Jesus are depicted. This cycle continues in the north wall, where the storyline focuses on the Wise Men: the journey of the Magi, the adoration of the Magi, and finally the Road to Egypt. ${ }^{10}$

The dubious state of the wall paintings unfortunately renders their stylistic analysis and dating more difficult. Despite this the earlier historiography of the murals focused mainly on these two questions. First, Vlasta Dvořáková suggested placing the wall paintings in the thirteenth century and made a connection to Styrian art." However, this idea was soon challenged by Alojz Habovštiak and Josef Krása.

\footnotetext{
${ }^{3}$ Especially the interior went through radical changes. The church was originally covered by a wooden ceiling. This was replaced by a vaulted ceiling in 1720-1721. L. ŠÁŠKY, Idem p. 80. There was also a pulpit built in, and the medieval wallpaintings were covered in this period. A. VALEKOVÁ, K pamiatkovej obnove Kostola sv. Juraja, in Monumentorum tutela 21, 2009, p. 184.

${ }^{4}$ A. VALEKOVÁ, Idem p. 185-186.

5 This was the first time that the church came under any serious research.

${ }^{6}$ I want to express my gratitude here to Marián Keleši, the conservator of the murals who cordially helped my fieldwork in the church and explained the recent restoration works on the wall paintings.

${ }^{7}$ Archival photographs: Archív Pamiatkového úradu (APÚ), Bratislava 573/B, 573/C. Documentation of the previous restoration from 1966 and 1967/8: APÚ R 398, R573.

${ }^{8}$ There is also a second, Gothic layer preserved in the apse: the figures of standing Apostles.

${ }^{9}$ Josef Krása argued that in the upper level of the nave an Old Testament cycle (Adam and Eve, Abel and Cain, and the sacrifice of Abraham) was depicted. However, today not much is visible from this. Krása saw the wall paintings when they were discovered which probably granted him a more reliable visual source than what we can work with today. J. KRÁSA, Nástěnné malby v kostele sv. Jiř́ v Kostolanoch pod Tribečom, in Monumentorum tutela 2, 1967 , p. 117.

${ }^{10}$ The last scene in this wall is nearly invisible today. Krása suggested that perhaps this represented the Massacre of the Innocents. J. KRÁSA, Idem p. 120.

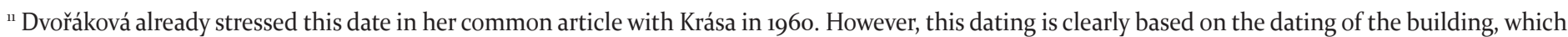
she dated to the thirteenth century depending on its southern portal. However, as it was already mentioned in this study, that part of the church is from a later phase than the original core which includes the murals. V. DVOŘÁKOVÁ - J. KRÁSA, Zpráva o prúzkumu slovenských nástěnných maleb konaném v zář́i 1960, in Umění 9, 1961, p. 199-201, V. DVOŘÁKOVÁ, Talianske vývinové prúdy stredovekej nástennej mal'by na Slovensku, in M. VÁROSS (ed.), Zborník Zo starších výtvarných dejín Slovenska, Bratislava, 1965, p. 227.
} 
While the former dated the murals to the eleventh century, the latter suggested for the terminus ante quem the second half of the eleventh century and emphasized the influence of Byzantine prototypes both stylistically and iconographically. ${ }^{12}$ Ján Bakoš also dated these paintings to around 1100 with the help of Czech book illumination..$^{13}$ A decade later, Melinda Tóth reinforced the dating of Dvořáková to the thirteenth century. ${ }^{14}$ She was the first who really analysed the iconography of these pictures, however, but only for the purpose of dating them. ${ }^{15}$ Hence Tóth argued that the wall paintings of Kostolany pod Tribečom were influenced by Byzantine stylistic tendencies mediated through Venetian art.

In the most recent dedicated publication on the church (a special issue of the journal Monumentorum tutela in 2009), Czech and Slovakian scholars harshly confronted this dating, and again relocated the murals in the first part of the eleventh century - as was argued in the study of Jana Maříková-Kubková and Tomáš Berger. ${ }^{16}$ They connected the compositional technique of the painter of the Kostol'any pod Tribečom murals to the wall paintings in the St Peter and Paul church in Reichenau, and his linear style combined with the vertical division of space to such early medieval pieces as the ninth century murals of the Santa Maria Antiqua church in Rome. ${ }^{17}$ I have also given attention to the genesis of these paintings, dating them with the help of roughly contemporary - and geographically closer - Czech miniature and wall painting analogies to the turn of the eleventh and twelfth centuries, and perhaps most probably to the first part of the twelfth. ${ }^{18}$

Even this brief overview on the historiography shows us that the stylistic analysis and date of the extraordinary murals of Kostolany pod Tribečom are still controversial in the scholarship and we cannot deal with them as a closed problem. However, as a result, the iconographic analysis was effaced in earlier research despite its singularity and delicacy. Therefore the aim of this article is to observe thoroughly the iconographical characteristics of three scenes of the cycle: the Annunciation, the Nativity, and the Magi on the road.

\section{ANNUNCIATION}

The first scene of the Nativity cycle depicts the Annunciation (fig. 2). Opposite of the usual arrangement of the two main characters, the dainty, long-sleeved figure of archan-

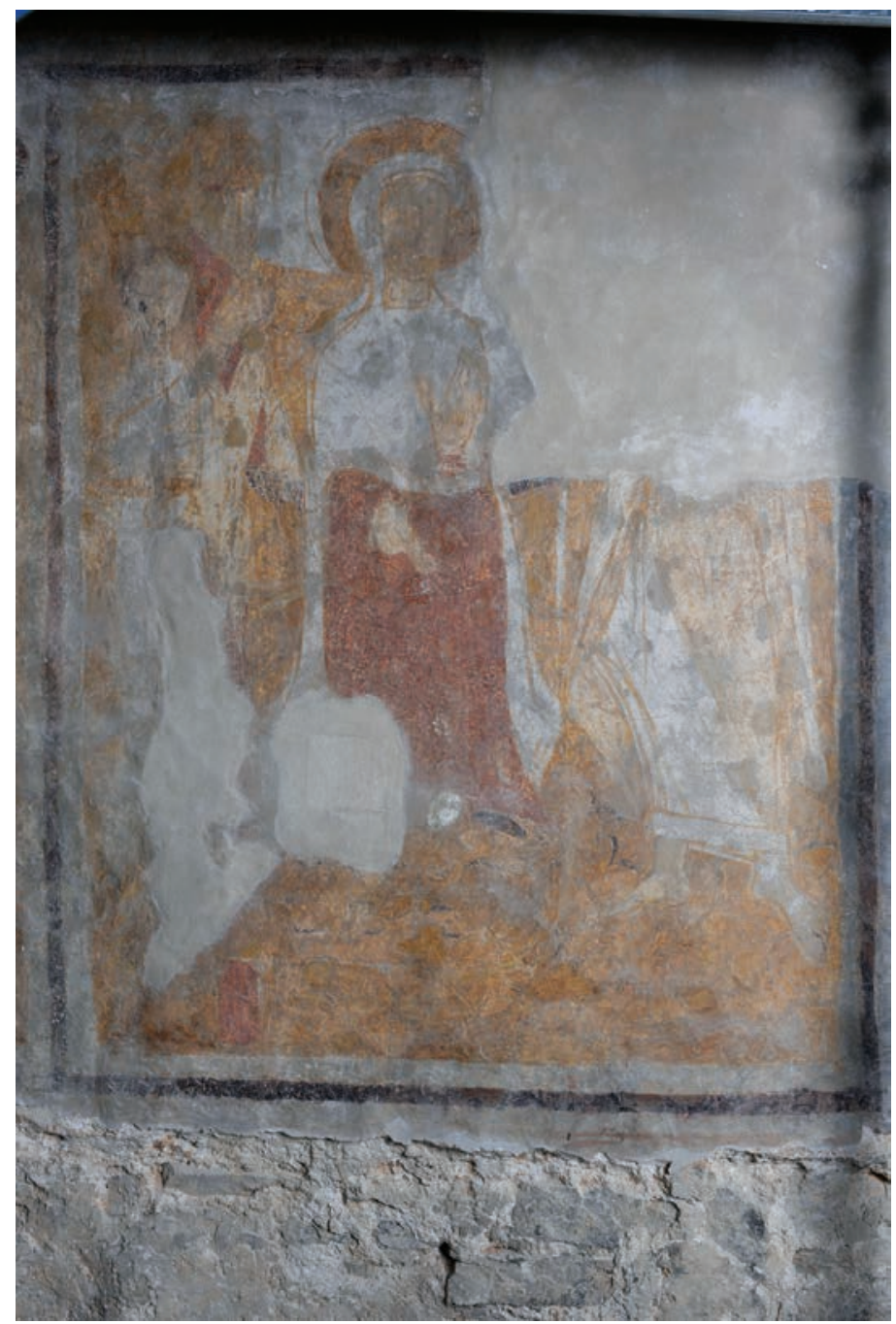

Fig. 2. Annunciation, c. 1100, wall painting, Kostolany pod Tribečom, St George Church, photo: Attila Mudrák.

gel Gabriel shows up in the right part of the image, while Mary is standing on the left. The locality of the picture is a neutral spot, only with a rough allusion in the background to the brown ground. Nevertheless, we can identify it more precisely as the interior of a room from the hanging curtains on both sides of the image. The most striking special feature of the picture are the two servant-maidens pulling open these curtains. This motif is incomprehensible in the local

\footnotetext{
${ }_{12}$ A. HABOVŠTIAK, Kirche mit Fresken in Kostolany pod Tríbečom, in F. JAN, Filip (ed.), VIIe Congres international des sciences préhistoriques et protohistoriques Tchécoslovaquie 1966, excursion en Slovaquie, Prague, 1966, p. 4, 6, 10, 14, 16, J. KRÁSA, op. cit. (n. 9) p. 115-127. Their theses were made possible by the research of Vendelín Jankovič and Ladislav Šášky, who suggested that the church was probably already existing in the tenth century. V. JANKOVIČ, Kostolany pod Tribečom, in Monumentorum tutela 2, 1967, p. 5-42,

V. JANKOVIČ, Archeologický výskum v Kostolanoch pod Tribečom, in Monumentorum tutela 4, 1968, p. 457,

J. JANKOVIČ, - L. ŠÁŠKY, Kostolany pod Tribečom, in Vlastidevný časopis 4, 1966, L. ŠÁŠKY, op. cit. (n. 2) p. 86-89.

${ }_{13}^{13}$ J. BAKOŠ, Genéza nástenných malieb v Kostolanoch pod Tribečom, in Vlastivedný časopis 17, 1968, p. 181. Milan Togner also suggested to date the painting cycle to the end of the eleventh century. M. TOGNER, Stredoveká nástenná mal'ba na Slovensku, Bratislava, 1988, p. 52-53.

${ }^{14}$ M. TÓTH, A kosztolányi templom falképei, in Ars Hungarica 1, 1974, p. 70, M. TÓTH, Árpád-kori falfestészet, Budapest, 1974, (Művészettörténeti füzetek, 9) p. 53-56.

${ }^{15}$ Tóth was the first to point out the similarities of the Magi wall paintings to the Sant'Urbano alla Caffarella in Rome, and the church in Lambach; the Annunciation to the San Marco cathedral in Venice, the Sant'Urbano alla Caffarella, and San Giovanni in Fonte in Verona; and also the Nativity to the cathedral in Palermo. However, to date the paintings, she argued that the type of the Nativity presented in Kostolany pod Tribečom could not have been tolerated the archaic representation of the Magi, and it became popular in north of the Alps only from the end of the twelfth century. I will argue that these criteria are in fact not always valid. M. TÓTH, Idem p. 64-70.

${ }^{16}$ J. MAŘíKOVÁ-KUBKOVÁ - T. BERGER, První stavební fáze kostela sv. Juraja Kostolanoch pod Tribečom, in Monumentorum tutela 21, 2009 , p. 148-151. ${ }^{17}$ Ibidem p. 137.

${ }^{18}$ My study on the wall paintings of the St George church in Kostol’any pod Tribečom: A gímeskosztolányi Szent György-plébániatemplom was already completed at the time of my presentation for this conference and also before finishing this paper. However, it is still under publication.
} 


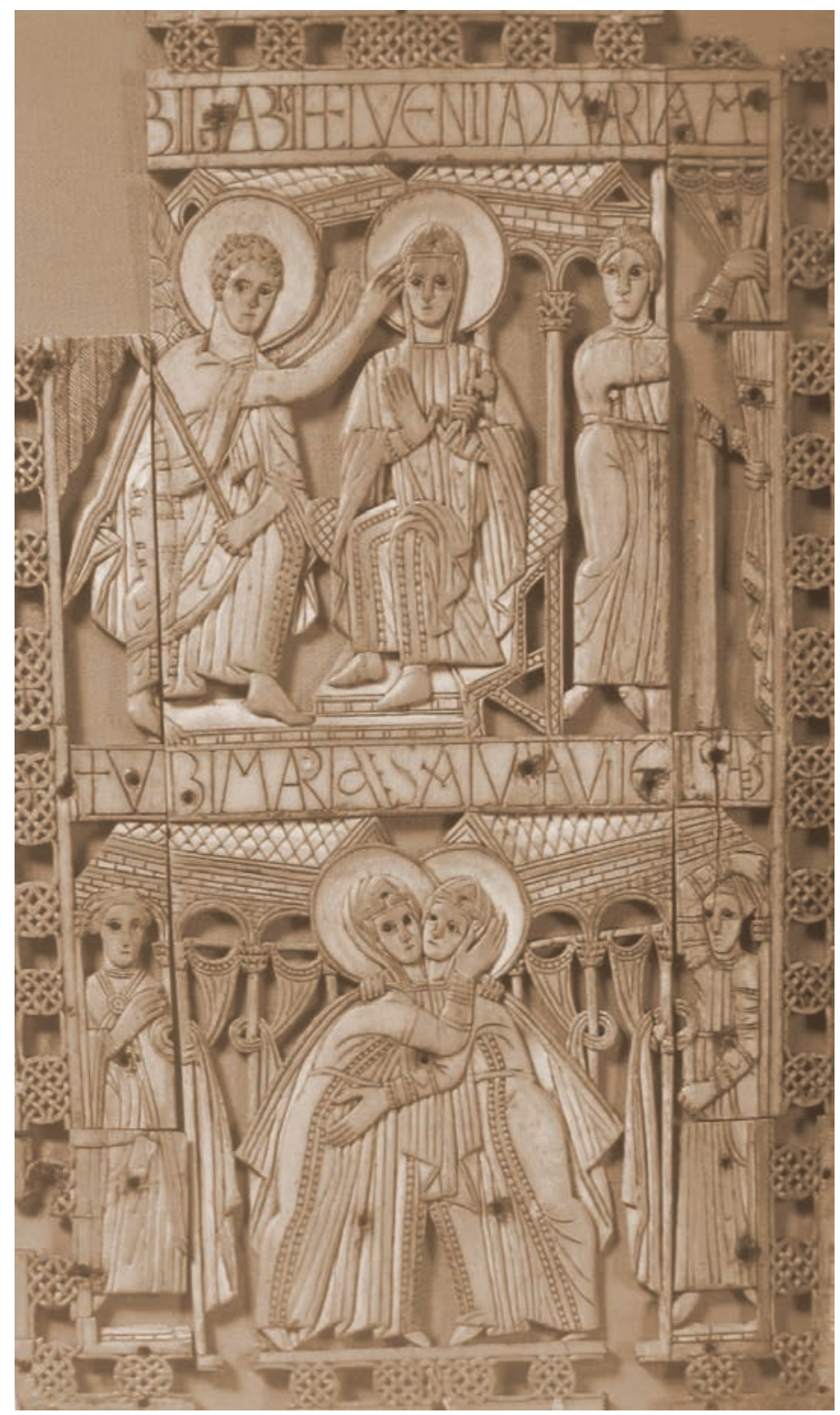

Fig. 3. Annunciation and Visitation, Genoels-Elderen diptych, back panel, ivory, $30 \times 18 \mathrm{~cm}$, pre-Carolingian (?), prov. Bavaria (?), Brussels, Musées Royaux de l'Art et d'Histoire, Musée du Cinquantenaire, no. 1474, photo: Goodness Shamrock.

iconographical tradition - but also odd in central European art in general, where the Annunciation mostly focuses on the duality of the two main characters.

To understand this curious scene in Kostolany pod Tribečom the earlier scholarship was content with the exp- lanation that this pattern came to central Europe from late Byzantine painting in the $13^{-14}$ th century. ${ }^{19}$ On one hand, if I suggest the eleventh or tweltfth century as the date of the mural decoration this seems rather too late for us. But on the other hand, I suppose there is an alternative from where the feature came to Kostol'any, still inside the frames of Western Europe. Nevertheless the figure of the servant maiden shows up later in Byzantine painting, the roots of this iconographic type go back to Mediterranean late antique art. ${ }^{20}$ The elaborate carving of the Genoels-Elderen ivory diptych (fig. 3) shows us the same scene as we can see in the wall painting of the small, isolated church of Kostolany pod Tribečom. ${ }^{21}$ Beside the Virgin and the angel a young maiden appears in the right edge of the panel. This ivory also helps us to enlighten the function of the servant maiden and so reveal how the image worked: next to the standing archangel Mary is sitting in the middle of the composition, in a space defined and limited by some archways. However, the servant girl is drawing the curtain which is hanging directly from the frame of the image, which suggests to us that her main purpose is to unfold this sacred scene to the spectator. Moreover, she is a viewer and witness to the Epiphany. This account is applicable to the aerial maiden of the Kostolany pod Tribečom wall painting, even though its rustic quality can be observed in how the painter carried out the scene: the girl draws the curtain from a separated little lodge in the background. This hints that he was working from a model that he could not understand entirely - a matter which I will return to in the following.

The wall painting of the Sant'Urbano alla Caffarella church in Rome was made about 1090 and thus we can see that this type of Annunciation was already in use in monumental painting by the time of the Kostolany pod Tribečom mural..$^{22}$ Many other surviving examples can indeed be dated to the eleventh and twelfth century, which perhaps shed light on the modest popularity of this archaic image at this time. Moreover they reveal to us the other possible interpretations of the motif: in the wooden ceiling panel of the St Martin church in Zillis the maiden was doing housework in the moment of the apparition of the angel, and through this subsequent position emphasizes the position of the Virgin as a noble matrona; while in the wall painting of the St Peter church in the Catalonian town of Sorpe she is one of the eight servants who were helping the Virgin to spin the carpet of the temple based on the apocryphal Infancy Gospel of James from the second century. ${ }^{23}$ Some of the later examples are very close to the earliest models, such

\footnotetext{
19 V. DVOŘÁKOVÁ, Dravce, in V. DVOŘÁKOVÁ, - J. KRÁSA - K. STEJSKKAL, Středověká nástěnná malba na Slovensku, Praha, 1978, p. 92, A. FALUDY, The "Annunciation" of Szepesdaróc, Iconography and Stylistic Relations, in Acta Historiae Artium 24, 1978, p. 83, B. GLOCKOVÁ, Dravecké Ukrižovanie a Zvestovanie, Otázka „južného vplyvu“ v stredovekej nástennej mal'be Slovenska, in Galéria, ročenka Slovenskej Národnej Galérie v Bratislave, 2002, p. 13.

${ }^{20} \mathrm{G}$. MILLET, Recherches sur l'iconographie de l'Évangelie aux XIV,$X V^{e}$ et XVI e siècles, Paris, $2^{\text {nd }}$ ed. 1960, p. 90. One of the earliest examples of the same servant maiden figures already shows up in the mosaics of the Euphrasian Basilica in Poreč from the middle sixth century, as I will refer to this in greater depth in the following.

${ }^{21}$ The provenance of the Genoels-Elderen ivories (today in the collection of the Musées Royaux de l'Art et d'Histoire, Brussels) is highly disputed. They were assigned both to Anglo-Saxon England, early Carolingian Francia, and most recently by Carol L. Neuman de Vegvar to pre-Carolingian Bavaria. C. L. NEUMAN DE VEGVAR, The Origin of the Genoels-Elderen Ivories, in Gesta 29, 1990, p. 8-24.

${ }^{22}$ Tóth already compared the Annunciation pictures of Kostolany pod Tribečom and the Sant'Urbano alla Caffarella. She dated them to the tenth century, however, recent scholarship argues that the paintings were made around 109o. M. TÓTH, A kosztolányi templom falképei, op. cit. (n. 14), p. 64, P. WILLIAMSON, Notes on the Wall-Paintings in Sant'Urbano Alla Caffarella, in Rome Papers of the British School at Rome 55, 1987, p. 227.

${ }^{23}$ The painted wooden ceiling of Zillis was made in the first decades of the twelfth century. J. THIES, Die Symbole der Romanik und das Böse, Die romanische Bilderdecke der Kirche St. Martin in Zillis/Graubünden im Fokus, 2007, 305. The wall painting of Sorpe can be dated to around 1125. M. OLIVAR DAYDÍ, The Art Museum of Catalonia, Barcelona, New York, 1968, p. 27. The story of the eight virgins can be read in the tenth chapter of the Infancy Gospel of James: R. F. HOCK (ed.), The Infancy Gospels of James and Thomas, Polebridge, 1995.
} 


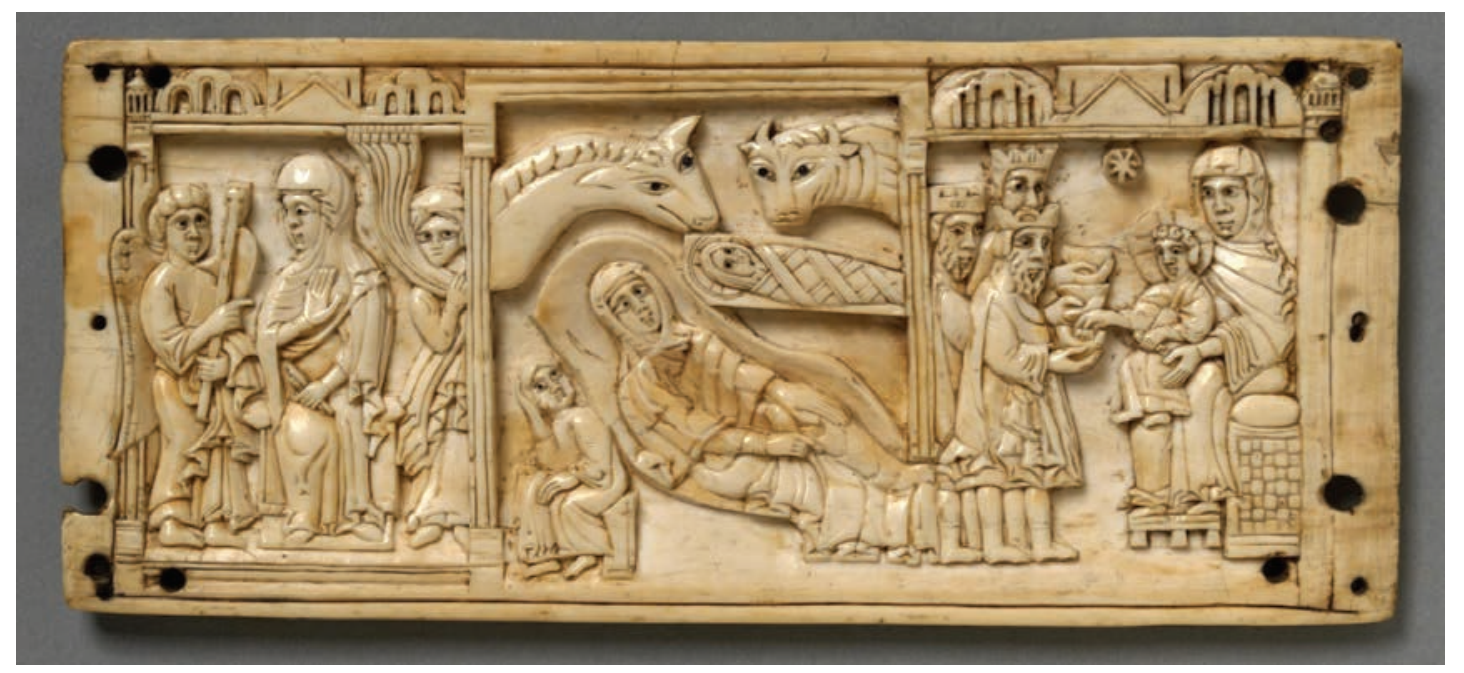

Fig. 4. Annunciation, c. 1200, ivory, prov. Central Italy, London, Victoria and Albert Museum, A.8-1933, photo: (C) Victoria and Albert Museum, London.

as the ivory plate of the Victoria and Albert Museum from around 1200 (fig. 4) which shows the maidservant drawing open the curtain from the top of the scene, in a manner similar to the Genoels-Elderen dyptich. ${ }^{24}$ The Kostolany pod Tribečom piece in one particular feature differs from all the listed examples: in contrast to the usual order the Virgin Mary is shown in the left part of the picture, while the angel arrives from the right-hand direction. This arrangement very rarely occurs in Annunciation pictures, but suggests that the model of the Kostolany pod Tribečom mural had a peculiar iconography. ${ }^{25}$

Curiously enough the motif of the maiden appears in the next scene, the Visitation wall painting (fig. 5 ) of Kostolany pod Tribečom as well. Beside the two central figures of Mary and Elizabeth, in both edges of the image a servant maiden draws back the curtain (fig. 6). Obviously, this feature is embedded to the same iconographical tradition as the Annunciation. The maiden is preserved in the case of the Visitation in even earlier examples than the Annunciation, such as the mid sixth-century mosaic of the Euphrasian Basilica in Poreč (fig. 7) ${ }^{26}$ The aformentioned Genoels-Elderen diptych - which includes the maidservant in the Visitation - also includes two extra persons in the Visitation scene, which is placed on the lower part of the ivory plate. ${ }^{27}$ Beside Kostolany pod Tribečom the illumination of the St Albans Psalter made around 1125-1140 attests that the image type could still be found in the beginning of the twelfth century. ${ }^{28}$ However, it seems that these could be in fact the

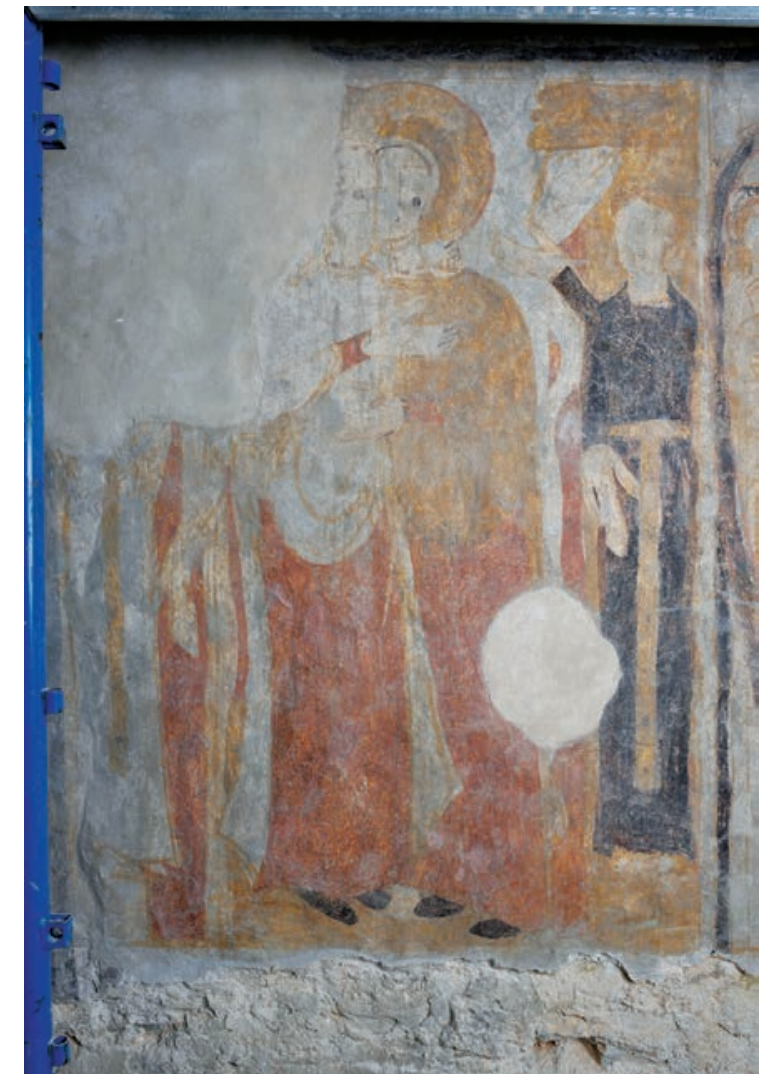

Fig. 5. Visitation, c. 1100, wall painting, St George Church, Kostol'any pod Tribečom, photo: Attila Mudrák.

${ }^{24}$ It is worth to note that the autenthicity of this plaque is not without any doubt. Williamson still convincingly dates it to around 1200-1230. P. WILLIAMSON, Medieval Ivory Carvings, Early Christian to Romanesque, Victoria and Albert Museum, London, 2010, p. 354-355.

${ }^{25}$ The previous scholarship ignored the curiosity of the arrangement. This motif is rare; however, it is not without analogies, eg. another ivory of the Victoria and Albert collection from the first half of the eleventh century. Ibidem p. 222-223.

${ }^{26}$ The mosaics can be dated to the middle of the sixth century with the help of their inscriptions. Even though today can be seen in a severely over-restored state, the iconography of the image originates from the late antique era. M. VICELJA-MATIJAŠIČ, Mosaics and Church Decoration, The Cathedral in Poreč, in P. BOKODY (ed.), Image and Christianity, Visual Media in the Middle Ages, Pannonhalmi Föapátság, July 3-September 30, 2014, Pannonhalma, 2014, p. 101. ${ }^{27}$ However, Neuman de Vegvar argued that in fact we can see the Annunciation of Zacharias in the background of the Visitation scene, and instead of two maidens the angels and Zacharias are standing next to the curtains. C. L. NEUMAN DE VEGVAR, op. cit. (n. 21) p. 8, 13-14. Koehler observed that this feauture appears in certain Carolingian illuminations, eg. The Harley Gospels, the Gospel of St Médard de Soissons, or the Gospels of St Augustin. W. KOEHLER, An Illustrated Evangelistary of the Ada School and its Model, in Journal of the Warburg and Courtauld Institutes 15, 1952, p. 48-66. As I see, in the case of the Genoels-Elderen dyptich it is hard to decide certainly which scene can be seen. In one hand, the two figures wear different clothes, which is rather atypical for the scene with the maidens. On the other hand, in contrast to the angel of the Annunciation above the person in the left of the Visitation does not have any wings. So contrary to the juxtaposed opinions I think it is more likely that the two maiden servants are represented here.

${ }^{28}$ The illumination of the St Albans Psalter, produced in England around 1125-1140, depict the same type of Visitation with the two maidens on the sides. There are a number of recent publications on the illuminations of the Psalter, as: K. EDMONDSON HANEY, The St. Albans Psalter, An Anglo-Norman Song of Faith, New York, 2002, J. GEDDES, The St Albans Psalter: a book for Christina of Markyate, London, 2005, K. M. COLLINS, The St. Albans Psalter, Painting and Prayer in Medieval England, Los Angeles, 2013. 

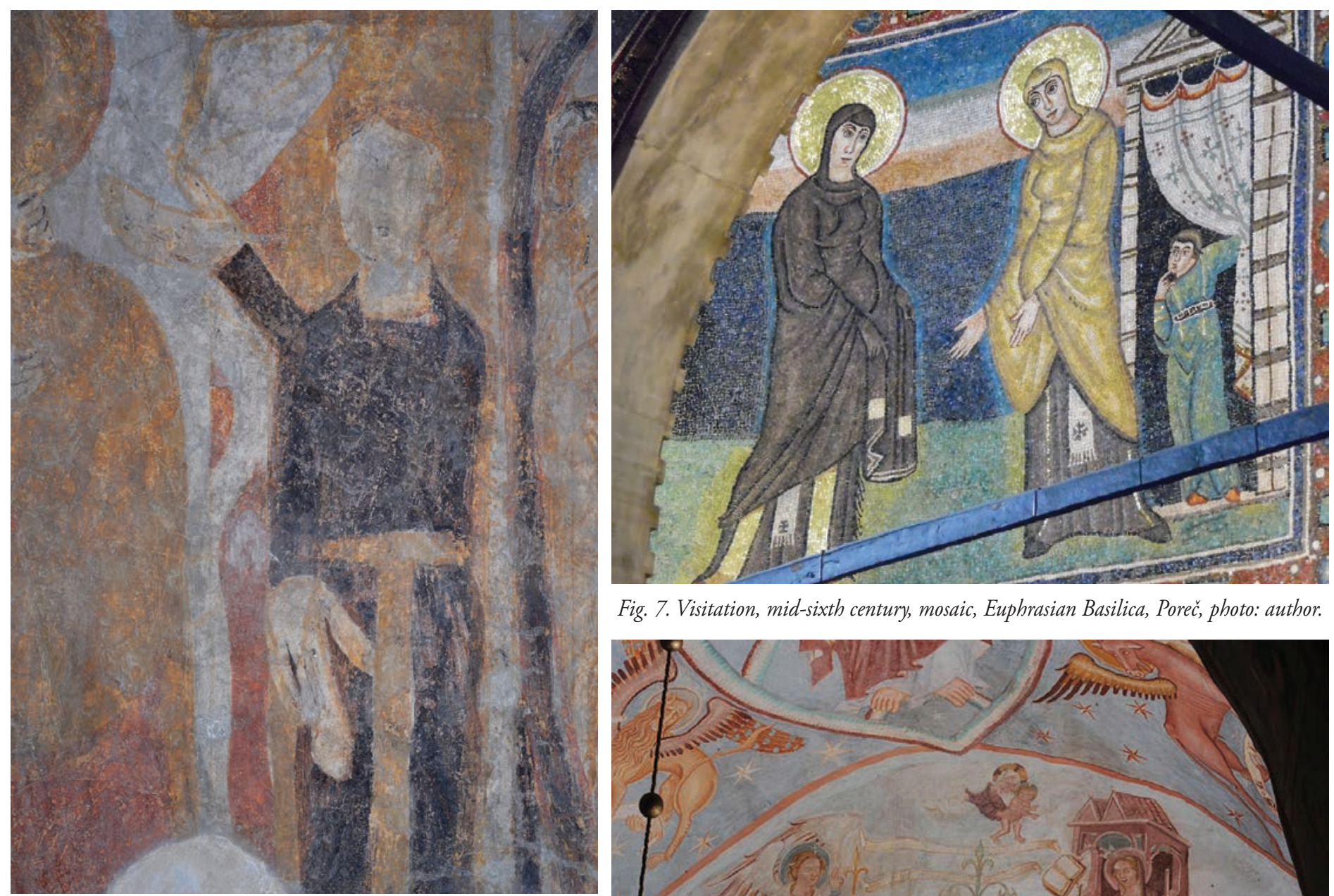

Fig. 7. Visitation, mid-sixth century, mosaic, Euphrasian Basilica, Poreč, photo: author.

Fig. 6. Visitation (detail), c. 1100, wall painting, St George Church, Kostol'any pod Tribečom, photo: Attila Mudrák.

swan-song of the iconographical type, which the last known example of is the Visitation mosaic of the north transept of the San Marco cathedral in Venice which was produced just after 1200. ${ }^{29}$

Contrarily, the version of the Annunciation containing a servant maiden survived in the Byzantine tradition even into the late medieval period. However, in western Europe I can list only two surviving later wall paintings, and surprisingly both from the northern part of the former Hungarian kingdom, curiously similar to Kostolany pod Tribečom. ${ }^{30}$ The fourteenth-century mural of Dravce and the fifteenth-century wall painting of Poruba (fig. 8) both represent a sleeping servant maiden who is sitting on the ground and graciously holding up her tumbling head with her left hand..$^{11}$ This motif shows up and flourishes in late Byzantine art: one of its finest examples is a sixteenth-century icon from Moscow. ${ }^{32}$ For this reason, I think, the two later images of Dravce and Poruba can be traced back to a different iconographical tradition and therefor different models than the mural of Kostolany pod

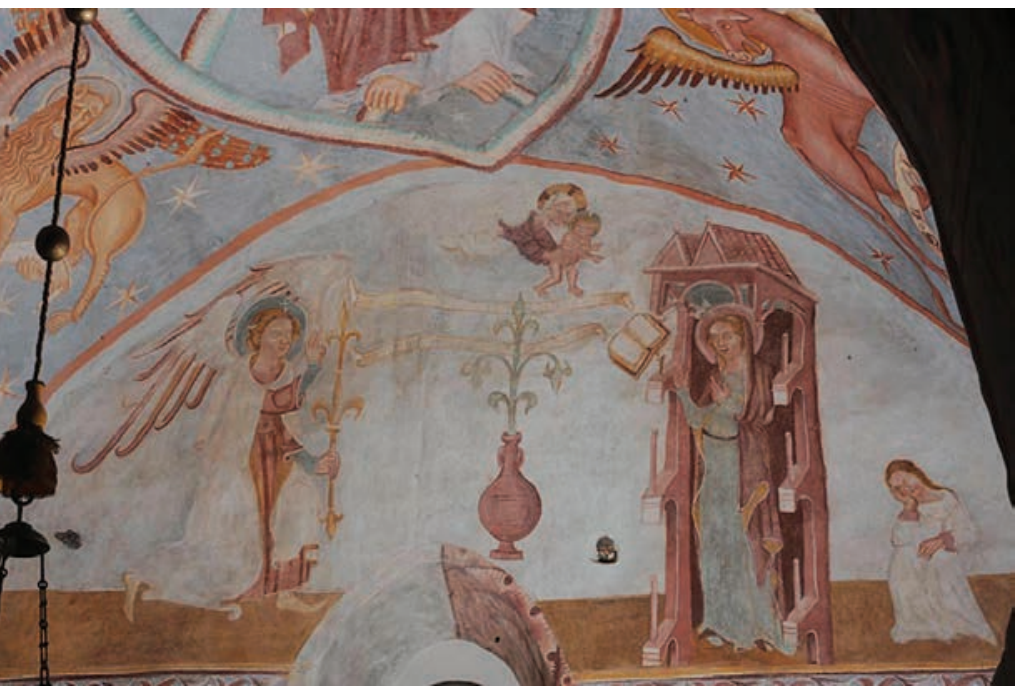

Fig. 8. Annunciation, early fifteenth century, wall painting, Poruba, St Nicholas Church, photo: Attila Mudrák.

Tribečom. As I will express later, I do not intend to argue that its painter directly studied the late antique and Carolingian models, but I suppose that he should have worked with some mediating material that transmitted the iconographical type of those ancient visual sources.

\section{NATIVITY}

The last scene of the south wall depicts the Nativity of Jesus (figg. 9-10). The focal point of this excessively dense composition is the magnified, prone Virgin Mary who axially divides the picture and occupies nearly one third of the space.

\footnotetext{
${ }_{29}$ O. DEMUS, Die Mosaiken von San Marco in Venedig, Wien, 1935, p. 34-35.
}

${ }^{30}$ There is also a baptismal font in the San Giovanni in Fonte church in Verona which can be dated to the thirteenth century. However, in this case we can observe two servant maidens on each side of the scene. V. CAVALLARI, Verona e il suo territorio, II, Verona, 1964, p. 737-738.

${ }^{31}$ About the Annunciation wall painting in Dravce see n. 19. The earlier scholarship unfortunately did not pay any attention for the unique iconography of the wall painting in Poruba, nor did it connect with Dravce and Kostolany pod Tribečom: V. DVOŘÁKOVÁ, Poruba, in V. DVOŘÁKOVÁ - J. KRÁSA - K. STEJSKAL, op. cit. (n. 19) p. 131, A. BOTEK, Nástenné malby v Kostole sv. Mikuláša v Porube, in Pamiatky a múzeá 3, 2009, p. 49-55.

${ }^{32}$ Iconostasis, 114.3 X $146 \mathrm{~cm}$, tempera on wood. In the collection of the Kremlin, Moscow.

33 L. BRUBAKER - J. HALDON, Byzantium in the Iconoclast Era, c. 680-850, A History, Cambridge, 2011, 330-332. 


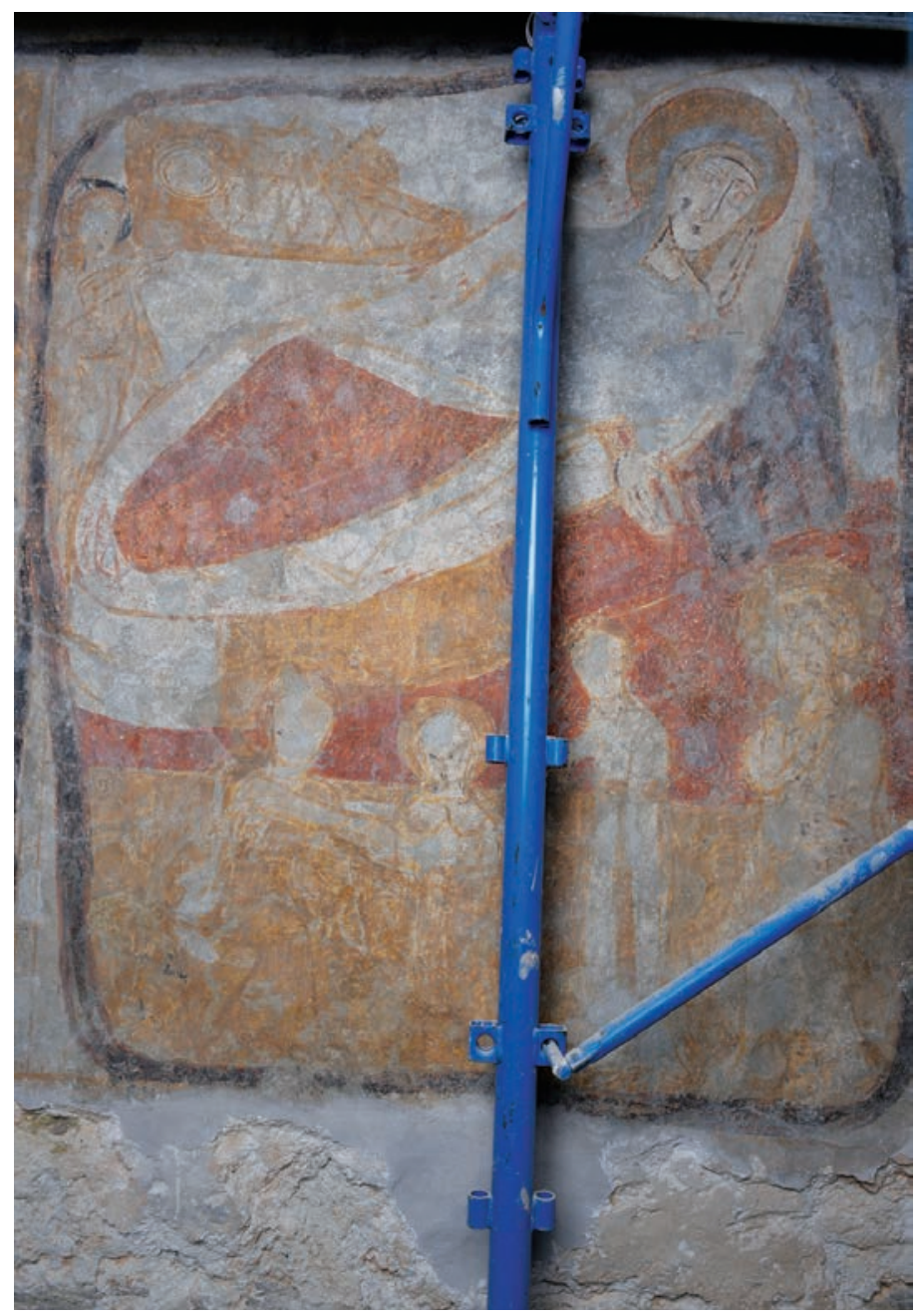

Fig. 9. Nativity, c. 1100, wall painting, St George Church, Kostol'any pod Tribečom, photo: Attila Mudrák.

Behind her dominant figure, the newborn child appear in the manger, framed by an ox and an ass. In the foreground two maidens are bathing the little Jesus. Joseph is sitting to the right of them, leaning on his stick. The composition and its characteristic forms - such as the oval-shaped bed of the Virgin Mary, the tightly wrapped-up child, or the artistic solution of the bathing scene - are all references to a certain archaic iconography. The peculiar image with its strict, concentric arrangement evolved in early Byzantine and Coptic art. The first preserved examples of the picture can be seen of seventh and eighth-century icons from St Catherine's monastery in the Sinai. ${ }^{33}$ One of its finest examples is an eleventh-century icon from Sinai. ${ }^{34}$ This picture presents how detailed and elaborate the composition became over time: it also includes the arrival of the Magi, the Massacre of

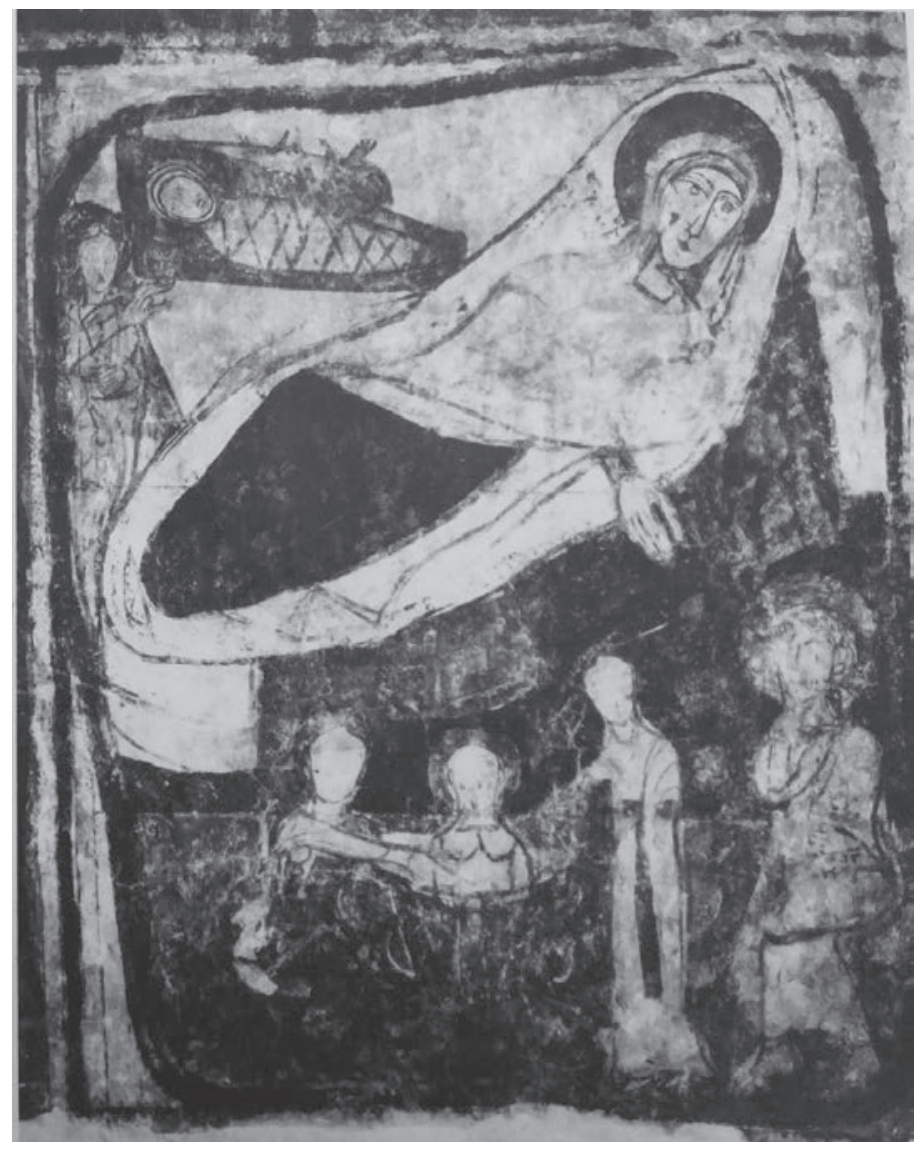

Fig. 10. Archival photo about the Nativity wall painting in Kostolany pod Tribečom, Bratislava, Archiv Pamiatkového úradu Slovenskej republiky, R 573C.

the Innocents and how Elizabeth and the infant St John the Baptist are escaping from the soldiers of Herod, the flight to Egypt, and a few other apocryphal scenes as well.

From the various scenes of the Kostolany pod Tribečom cycle the Nativity is the only picture which in fact became quite popular both in western and in eastern Europe during the high middle ages. ${ }^{35}$ This offers us the possibility to imagine vaguely how the transition of an image worked in a longue durée. Nativity scenes of this type were common in the middle Byzantine period although filtered by contemporary discourse could still faithfully transmit composition and features of earlier pieces. ${ }^{36}$ However, it should be emphasized that the composition also became and remained popular in the Italian peninsula. One of its first examples, the eighthcentury mosaic of the Old St Peter's cathedral in Rome was contemporary of the first surviving Byzantine and Coptic icons. ${ }^{37}$ The imagery initially became common in the Macedonian period (ca. 867-1056) in Byzantium and then flourished in the eleventh and twelfth centuries. ${ }^{3}$ Main pieces of

\footnotetext{
${ }^{34}$ H. BELTING, Bild und Kult, Eine Geschichte des Bildes vor dem Zeitalter der Kunst, München, $4^{\text {th }}$ ed. 2004, p. 313, R. S. NELSON (ed.), Holy Image, Hallowed Ground, Icons from Sinai, J. Paul Getty Museum, Los Angeles, Nov. 14, 2006-Mar. 4, 2007, Los Angeles, 2007, cat. n. 14.

35 Indeed for this reason I will mention here only a few of the numerous examples of these sorts of Nativity pictures which I found useful enough to refer to them here directly - which means that I did not intend to give a thorough analysis how the image emerged and changed. However, the literature of the few listed pieces that I referred to in the following notes give a introduction to the topic, that because of its measures I could not discuss here in more detail. It should be also noted that this Nativity picture remained popular even in the late medieval period as well.

${ }^{36}$ In general about the same type of Nativities: J. LAFONTAINE-DOSOGNE, Les représentations de la nativité du Christ dans l'art de l'orient chrétien, in Miscellanea codicologica F. Masai dicata 1, 1979, p. 11-21, E. KITZINGER, The Mosaics of St. Mary's of the Admiral in Palermo, Washington, D. C., 1990, (Dumbarton Oaks Studies, 27) p. 175.

${ }_{37}$ We can have an idea about the mosaic through drawings and also some minor fragments. P. J. NORDHAGEN, The mosaics of John VII (705-707 A.D.), in Acta ad archaeologiam et artis historiam pertinentia 2, 1965, p. 121, 130. also the images: 7-9, 18, 20.

${ }^{38}$ E. KITZINGER, op. cit. (n. 36) p. 176. Some of the best examples are already listed by Kitzinger, such as the mosaic of Daphni: E. DIEZ - O. DEMUS, Byzantine Mosaics in Greece, Daphni and Hosios Lucas, in Byzantine mosaics Journal of Hellenic Studies 52, 1932, fig. 84, the illumination of the Phocas Lectionary in the Lavra on Mount Athos: K. WEITZMANN, Das Evangelion im Skevophylakion zu Lawra, in Seminarium Kondakovianum 8, 1936, p. 83,
} 


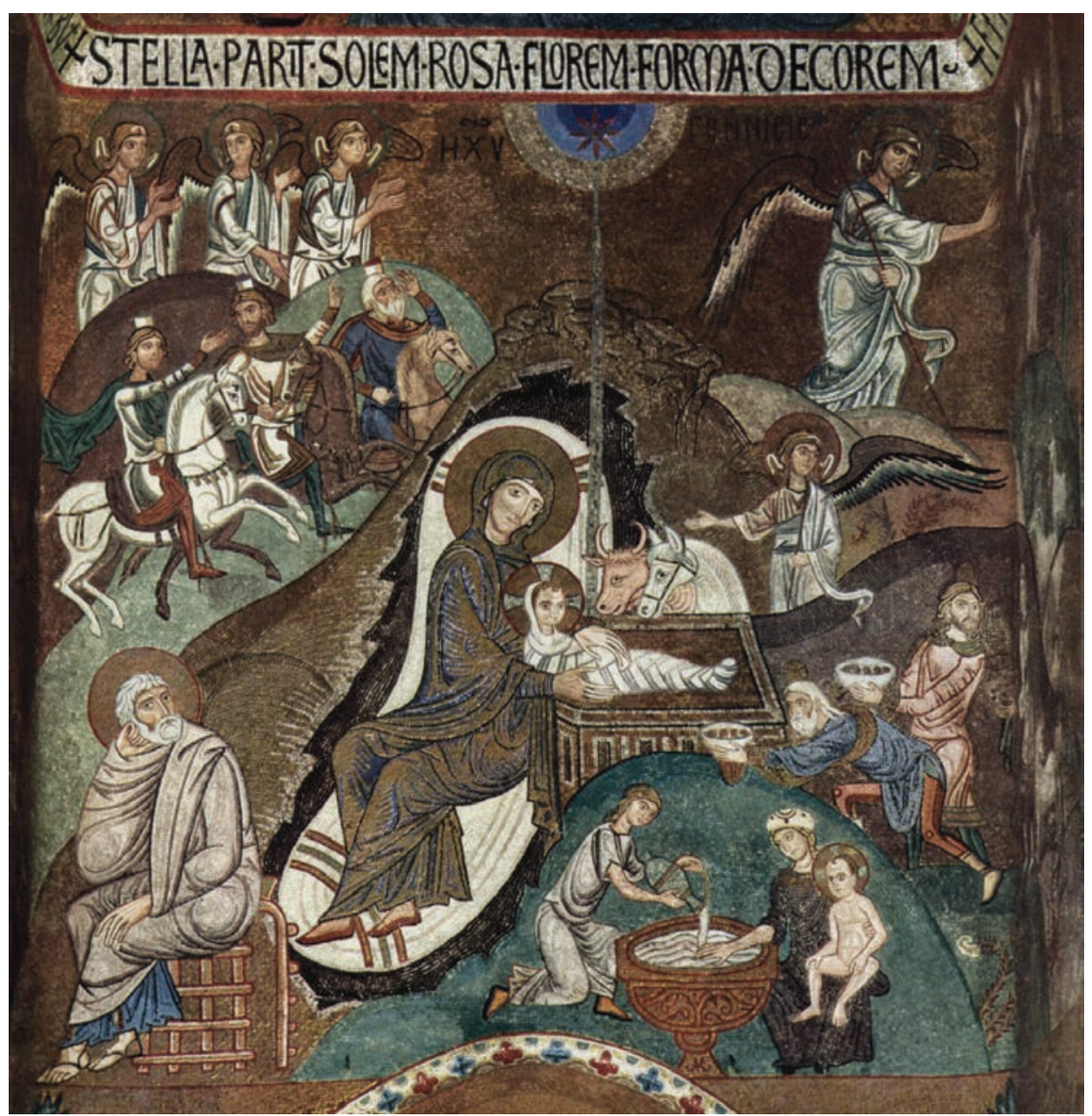

Fig. 11. Nativity, mid-twelfth century, mosaic, Cappella Palatina, Palermo, photo: The Yorck Project Gesellschaft für Bildarchivierung GmbH.

twelfth-century monumental art such as the mosaic of the Cappella Palatina (fig. 11), or of the Martonara church, both in Palermo can be mentioned here. ${ }^{39}$ The former example is also combined with the arrival of the Magi, who appear in separate scenes in Kostolany pod Tribečom. Observing the strong connection between the Italian mosaics and their Byzantine prototypes we can claim that the art of the peninsula could mediate this image type to Western Europe.

The characteristic composition and the same formsolutions imply that in the case of these images the artists were not just working from similar descriptions of the artistic manuals, or described by their patrons, but indeed, they should have been inspired by the same visual sources. It can be referred here that this scene was also depicted in several portable icons, illuminations and ivories as well, which, as
I see, should obviously have had an important role in the transmission of earlier models. Indeed, the illuminations and ivory plates represent the closest analogies of the wall painting in Kostolany pod Tribečom. The tenth century Byzantine Nativity ivories in the Louvre and the Walters Art Museum (fig. 12), or the illumination of the Egbert Psalters all reveal essential compositional and iconographical similarities with the Kostolany mural..$^{\circ}$ If we look closely at the wall painting, we can observe a standing person in the background, near the left edge of the picture. He has been entirely ignored by previous scholarship. He is wearing a long tunic and was captured in a move as if he is stepping into the scene: he is turning to the direction of the Virgin Mary and making a pointing gesture with his right hand. In the ivory of the Walters the same upper part of the image includes three similar persons, who are moving closer to the scene of the birth of Jesus and making the same sort of pointing gestures. However, we cannot see in any of these two cases what they are precisely doing. Other images, such as the Louvre ivory or the two Sinai icons suggest to us that they are leading the Magi or the shepherds to the infant Jesus. ${ }^{41}$ Therefore I assume that we can see an angel in the mural of Kostolany pod Tribečom as well. While the Walter ivory already shows a reduced version of the image, the artist of the Kostolany wall painting went further when simplified the composition of the group of the - usually three, but sometimes even more - angels and shepherds or Magi radically to a single angel.

\section{THE THREE WISE MEN}

The peculiarity of the Magi pictures (figg. 13-16) in Kostolany pod Tribečom manifests itself through two main features: the non-kingly representation of the Magi, and their lengthy exposition in two whole scenes, as well as a reference in the Nativity scene. As I intend to present here, none of these traits were common after the first millennium, and definitely not in the turn of the eleventh-twelfth century. At this

and also from Mount Athos the illumination of the Ms. 837m, Dionysiou: G. A. CHRISTOPULOS - J. C. BASTIAS (ed.), Treasures of Mount Athos, III, 1979, fig. 250, etc.

${ }^{39}$ The Cappella Palatina scene is also combined with the arrival of the Magi - who are appearing in separate scenes in Kostolany pod Tribečom. On the iconography of the Nativity scene: C BODINEK: Die Cappella Palatina in Palermo, Ikonographische Studien zu ihrer Mosaikausstattung durch die Normannenkönige (1130-1189), Weinstadt, 2014, p. 82-107. One of also the newest publication on the Nativity of the Cappella Palatina summarising the earlier literature as well: B. BRENK, Scena della Natività, in B. BRENK (ed.), La Cappella Palatina a Palermo, I, Modena, 2010, p. 474-475. For the Martonara church, also called St. Mary's of the Admiral: E. KITZINGER, op. cit. (n. 36) p. 175-181, 310-312.

${ }^{40}$ About the plaque of the Louvre: D. GABORIT-CHOPIN, Ivoires médiévaux, Ve - XVe siècle, Paris, 2003. About the plaque of the Walters: R. H. RANDALL, Middle and Late Byzantine Ivories, Catalogue, in R. H. RANDALL (ed.), Masterpieces of Ivory from the Walters Art Gallery, New York, 1985 , p. 126. The illumination can be seen in the fol. 9v of the Egbert Psalters. Its iconography shows strong Byzantine connections. I. SPATHARAKIS, The Portrait in Byzantine Illuminated Manuscripts, Leiden, 1976, p. 39.

${ }^{41}$ In the case of the older examples like the Sinai icons it is more typical that the angels are leading the Magi - while later, mainly from the tenth century, such as in the Louvre ivory they are more often leading the shepherds. 


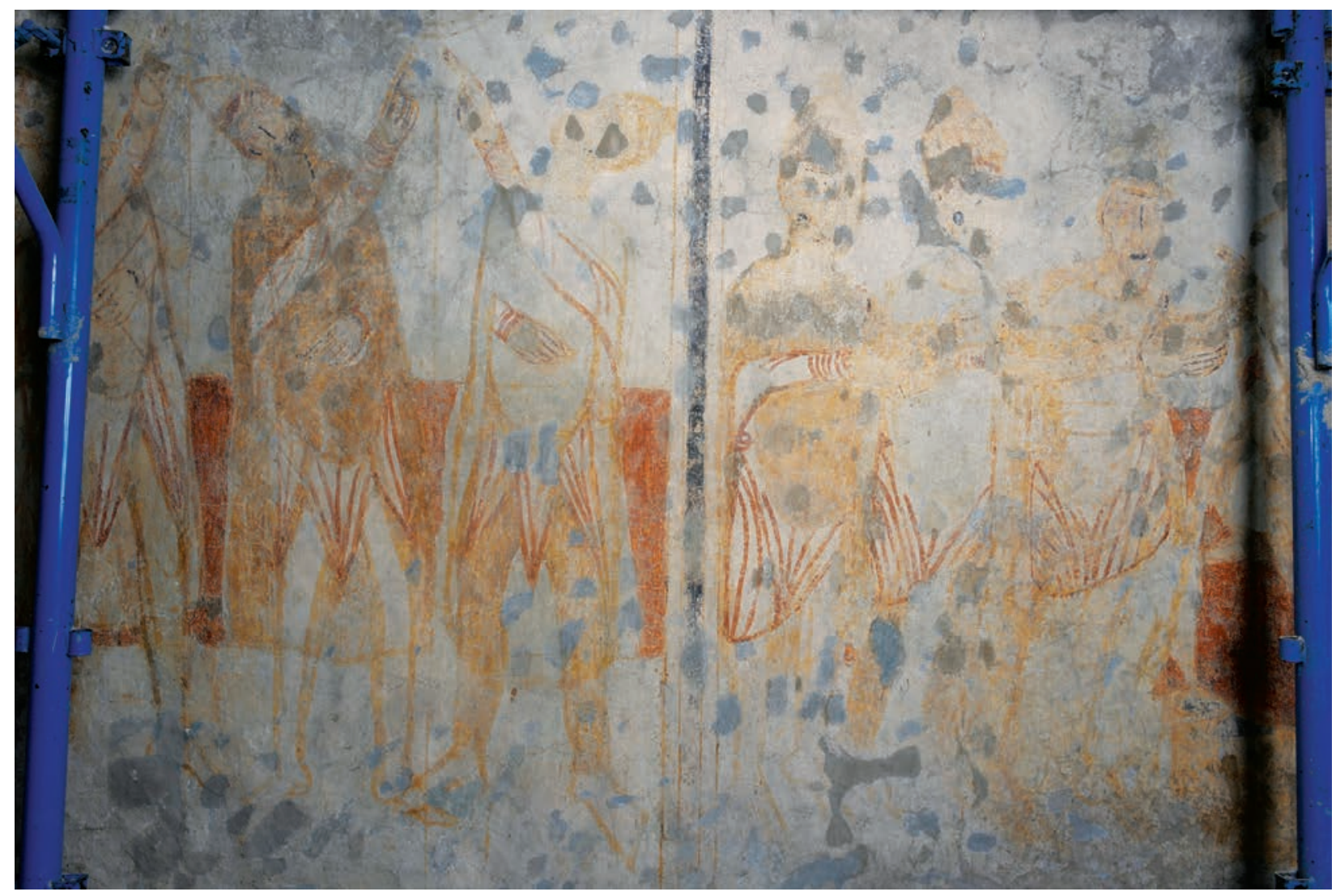

Fig. 13. Journey of the Magi and the Adoration of the Magi (detail), c. 1100, wall painting, St George Church, Kostol'any pod Tribečom, photo: Attila Mudrák.

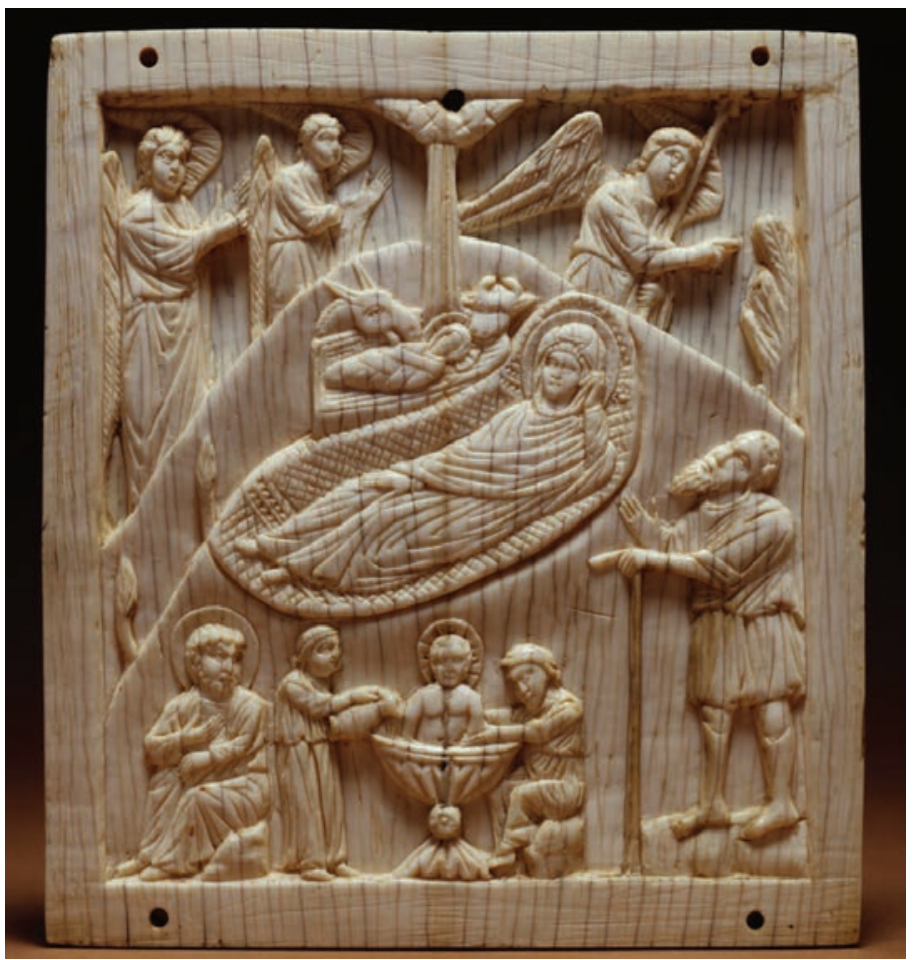

Fig. 12. Nativity, tenth century, ivory, $13.5 \times 12.3 \times 1 \mathrm{~cm}$, prov. Constantinople, Baltimore, Walters Art Museum, 71.305, photo: (C) Walters Art Museum. time, the Magi were already depicted as we are accustomed to today: the mighty kings from the East, in elegant clothes and with golden crowns on their heads. ${ }^{42}$ Their appearance is also confined to one scene: the adoration of the Christ child, who is usually sitting on the laps of the Virgin, and the Magi are prostrating before him, offering their presents from the East. Instead of this, in the church of Kostol'any pod Tribečom the Magi posess an extensive and unusual cycle.

Previously I pointed out that the angel in the Nativity picture was showing the way to the witnesses of the Epiphany, either the shepherds or the Magi. However, it is impossible to decide with certainty what the painter was thinking of, and in light of the great emphasis on the Wise Men in the mural decoration of the church, I think it is very likely that the angel was showing the way to the Magi. Thus this could have been quite a resourceful way to connect the scenes of the south and the north walls.

Looking at the north wall, in the first scene the Magi are depicted on their journey. The Three Wise Men are standing next to each other, and pointing up to the now badly weathered star, which was their guide to the newborn Jesus. In the third scene of the cycle, we can observe their procession to the infant. Standing on the left side, their bodies are turned in the direction of the child, but their heads are looking nearly frontally to the viewer, while they are holding their gifts with both hands. On the right side, the Virgin Mary is sitting

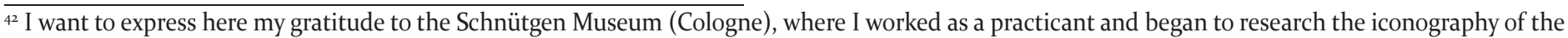
Three Wise Men through participation in the preparation of their Magi exhibition in 2014. Their catalogue offers the most recent publication and a very thorough overview of the topic: M. BEER - I. METJE - K. STRAUB (ed.): Die Heiligen Drei Könige: Mythos, Kunst und Kult [also published in English, which edition I will refer to in this study: The Magi, Legend, Art and Cult], Katalog zur Ausstellung im Museum Schnütgen, Köln, 25. Oktober 2014 - 25. Januar 2015, München, 2014. A general overview of the progress of the iconography of the Magi can be found: A. WEIS, Drei Könige, in E. KIRSCHBAUM (ed.), Lexikon der christlichen Ikonographie, I, Rom-Freiburg-Basel-Wien, 1968, col. 539-549. A more lengthy and substantial survey can be read in the fundamental work of Trexler, who also points out that in contrast to western Europe the Magi were traditionally not represented in medieval Byzantine art: R. C. TREXLER, The Journey of the Magi, Meanings in History of a Christian Story, Princeton, 1997, p. 9-75.
} 


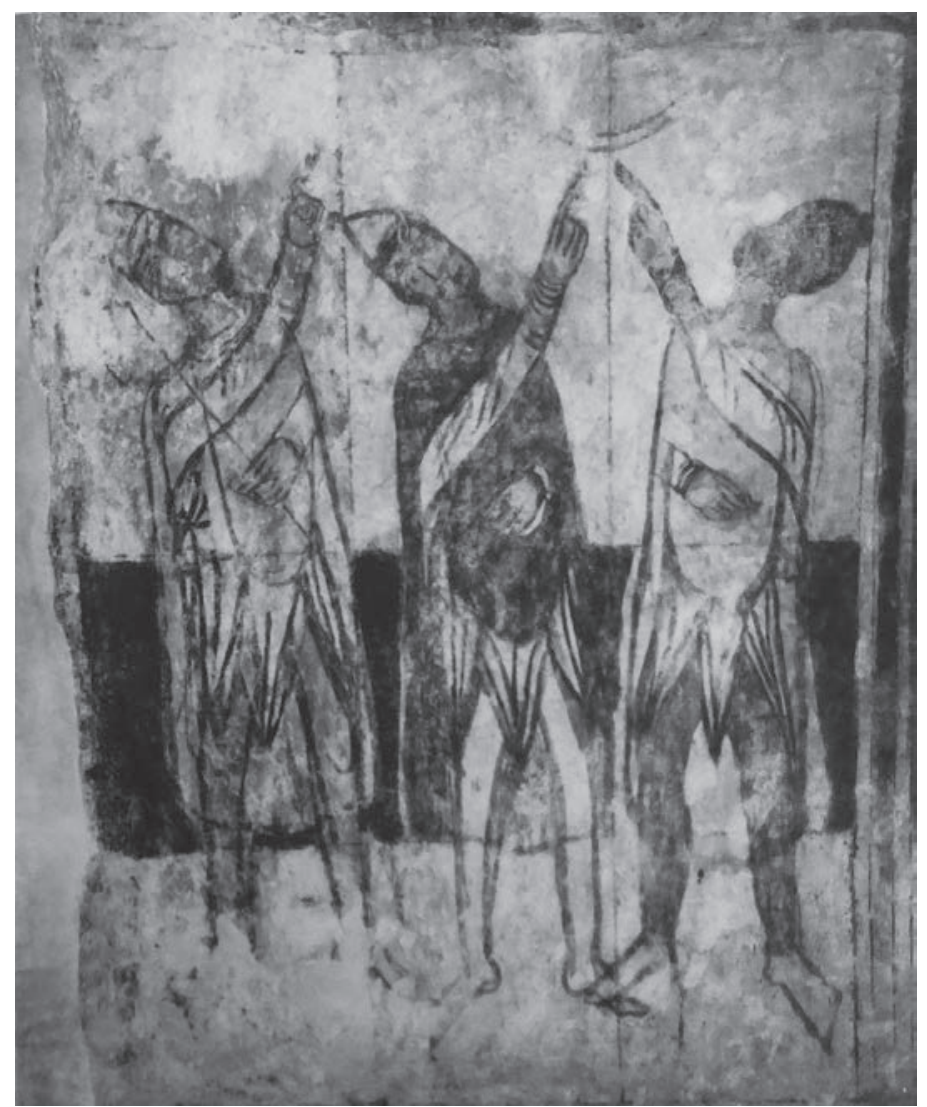

Fig. 14. Archival photo about the Journey of the Magi wall painting in Kostolany pod Tribecom, Bratislava, Archiv Pamiatkového úradu Slovenskej republiky, $R$ 573C.

majestically on a throne, and the Jesus child on her lap is receiving the gifts while raising his right arm for benediction (fig. 15-16). The last scene of the north wall depicts the flight into Egypt. Even though here we can see only the Virgin Mary with Jesus riding on an ass - they are escaping from the city after the visitation of the Magi, because they learned from the angel, who is presented here in the background, that Herod intends to kill the infants in Bethlehem. ${ }^{43}$

Already the plot of the cycle reveals a few extraordinary features. Nontheless, a few high medieval Magi cycles includes the separate scene for the journey of the Wise Men, in which cases they most often travel on horses. This is what we can see in the illumination of the St Albans Psalter from about 1130 as well, whose folios in many other way recall the paintings of Kostolany pod Tribečom. ${ }^{44}$ The Three Wise Men are represented as travellers without crowns, and we can see the Magi on their journey, pointing up to the star on the sky: the two on the left turn right, and the third to the opposite direction, just as in the case of our mural. In the next illumination, the composition is again built up generally in the same manner as of Kostolany pod Tribečom - except the

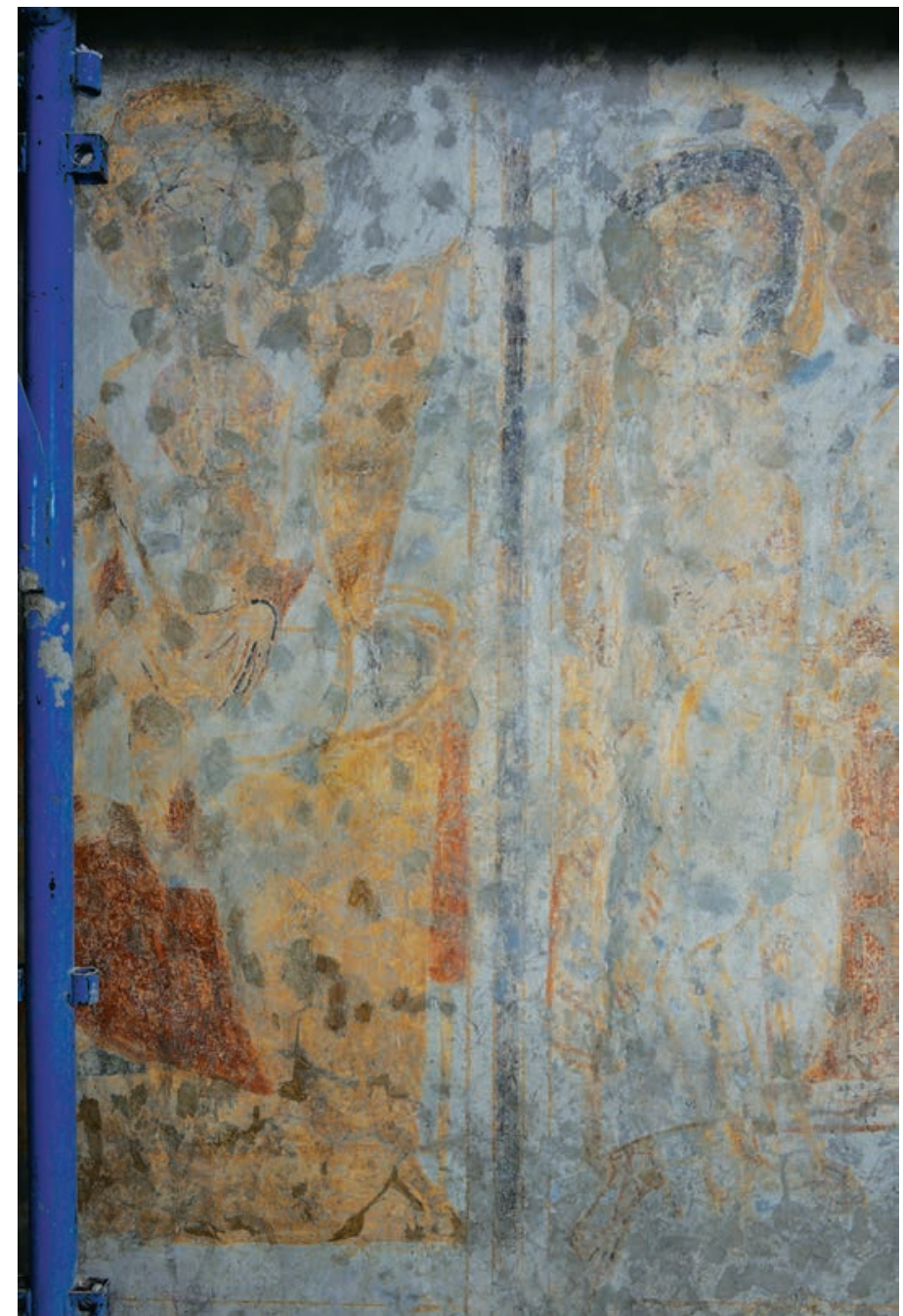

Fig. 15. The Madonna with Child on the adoration of the Magi (detail), c. 1100, wall painting, St George Church, Kostol'any pod Tribečom, photo: Attila Mudrák.

horse of one of the Wise Men. In fact, Kostolany represent a reminescent of the archaic images: in late antique art the Magi always travelled by foot while pointing up to the star or the sign of Christ. This move can already be seen in early fourth-century sarcophagus reliefs. 45

Their appearance recalls a similarly archaic imagination: the pre-Carolingian era, where the Magi were not visualized as kings, but as exotic eastern travellers. ${ }^{46}$ Hence originally they were wearing Persian clothes: the chiton, anaxarydes, and Phrygian hats. ${ }^{47}$ This is how they are depicted in their first preserved image, the early fourth-century wall painting of the Greek Chapel in the Priscilla Catacomb in Rome. ${ }^{48}$ While St Augustine had mentioned them as kings, the shift in their imagery happened only in the tenth century. ${ }^{49}$ Nevertheless, this later conception soon became popular

${ }_{43}$ This story also can be found in the Gospel of Matthew (2:13-20), following the visit of the Magi (Matthew 2:1-12).

${ }^{44}$ A. GOLDSCHMIDT, Der Albanipsalter in Hildesheim und seine Beziehung zur symbolischen Kirchensculptur des XII. Jahrhunderts, Berlin, 1895, 35, 139. For more recent literature see n. 28.

${ }^{45}$ T-M. SCHMIDT, Fragment of a Sarcophagus Lid, in M. BEER - I. METJE - K. STRAUB (ed.), op. cit. (n. 42) p. 29.

${ }^{46}$ The description of the gospel gave way to vague imaginings about the Magi. It is only certain that they came from the East, knew how to interpret stars, and gave gold, frankincense, and myrrh when they visited the Christ child.

${ }_{47}$ T. RAISON, The Legend of the Magi, in T. RAISON, - L. MARDER (ed.), We Three Kings, The Magi in Art and Legend, Buckinghamshire County Museum, 25 October 1995 - 21 January 1996, Buckinghamshire, 1995, p. 7.

${ }^{48}$ R. SHEPERD, The Magi in the Visual Arts, in Idem p. 14.

${ }^{49}$ On the conception of St Augustine of the Magi as kings (in the Serm. xx, De epiphania): H. KEHRER, Die Heiligen drei Könige in Literatur und Kunst, Leipzig, 1908, p. 13 . 


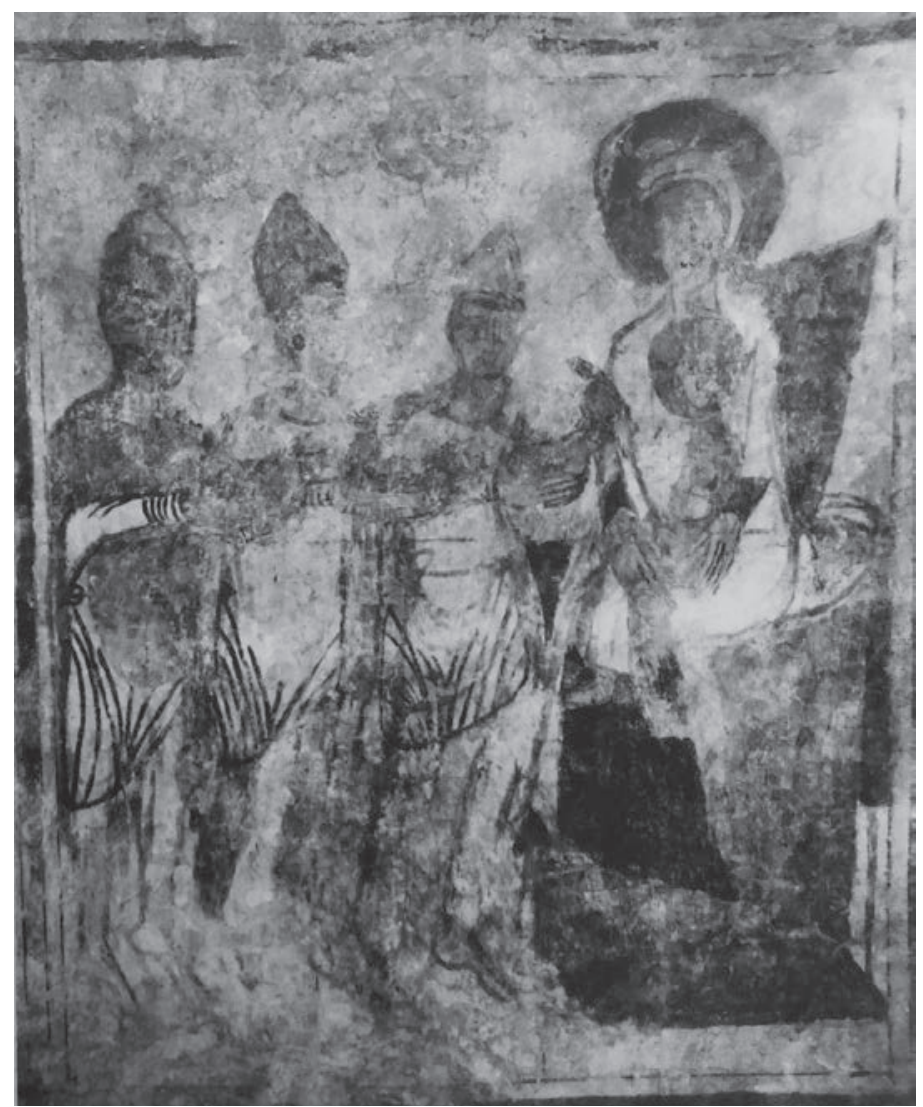

Fig. 16. Archival photo about the adoration of the Magi wall painting in Kostolany pod Tribečom, Bratislava, Archiv Pamiatkového úradu Slovenskej republiky, $R$ 573C.

and nearly totally displaced the former one..$^{50}$ After the first millennium only a handful of images preserved this original appearance, including the murals of Kostolany pod Tribečom. The imagery of this wall painting today seems drawn with rough, rustic contours, and coloured with fallow, muddy tones. The achievments of the recent restoration research reveals a reverse picture: on the journey scene the first Magi from the left wears vivid green pants and white tunic, the second white pants and a yellow outer garment, and the third yellow pants and blue tunic..$^{51}$ The main particularity of their clothes is the hanging triangular-shaped garments at the end of their chitons, which differentiate their outfit from most of the late antique and contemporary analogies. Some of the early Christian models, such as the relief on an early fourth century Algerian sarchophagus lid represents the lower end of the chiton of the Magi divided into three parts as they step..$^{22}$ However, in the case of these examples it is clearly visible that these clothes are part of the garment and their form is made by the movement of the persons who

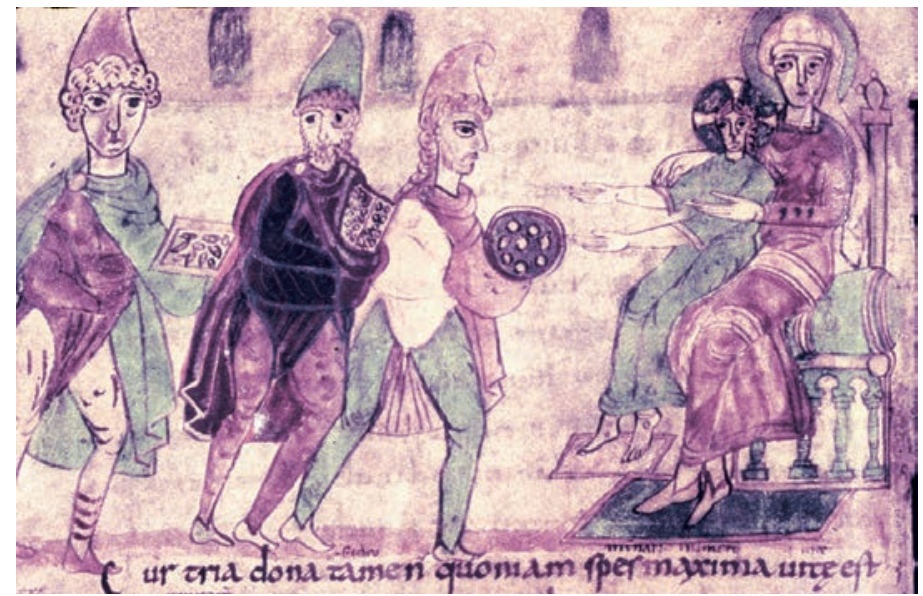

Fig. 17. Adoration of the Magi, second third of the ninth century, illumination, Antwerp, Plantin-Moretus Museum, M 17.4, fol. 15v, photo: courtesy of the Index of Christian Art, Princeton.

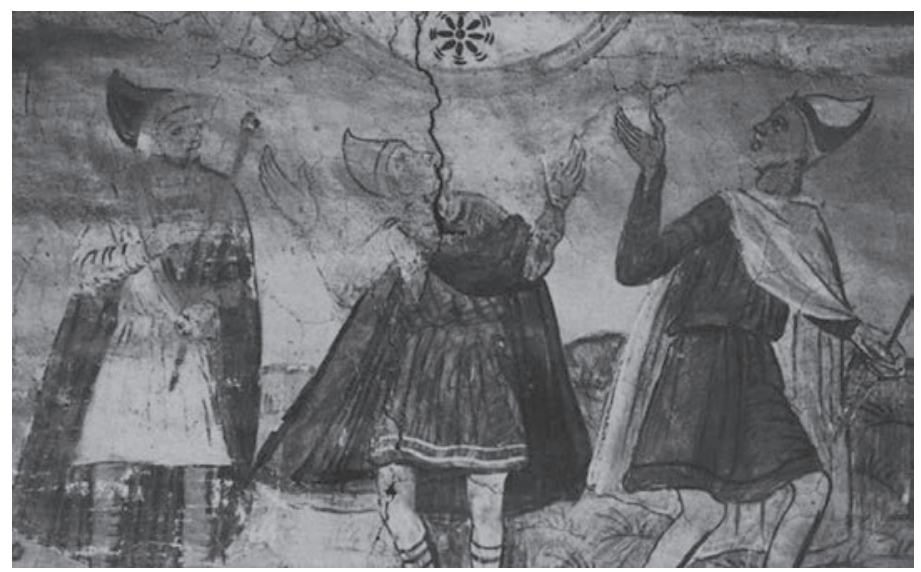

Fig. 18. The journey of the Magi, c. 1090, wall painting, Rome, Sant'Urbano alla Caffarella Church.

wear them. ${ }^{33}$ The inorganic nature of the garment in Kostolany pod Tribečom suggests that the painter was copying the old models, but could not understand entirely the structure of these clothes. We can observe a similar experiment in the illumination of the Sedulius Codex (fig. 17), which originated in Mainz from about the second third of the ninth century. ${ }^{54}$

The hat which the Magi are wearing in the wall painting in Kostolany pod Tribečom is also unique. Whether it is a Phrygian hat is not entirely evident; it is not quite as flat as the caps of the Magi in the St Albans Psalter. It shows a rather tall form, however, not as long as, for instance, the hats of the Wise Men in the Sedulius Codex, which is still one of the closest analogies. The wall paintings from about 1250 in the St Andrew church of Vizsoly, which also belonged to the Hungarian kingdom, offers an interesting

${ }^{50}$ The Magi always "spoke for power" as Trexler put it. R. C. TREXLER, op. cit. p. 56. Behind their coronation also lay political motivation and the use of them in royal propaganda, as Charlemagne already adopted it and this sort of use of their persons became more and more common from that time on. ${ }^{51}$ J. HRADILOVÁ - D. HRADIL - E. KOTULANOVÁ - S. ŠVARCOVÁ, Nástěnné malby v Kostolanech pod Tribečom, Materiály, technika a přičiny jejich poškození, in Monumentorum tutela 21, 2009, p. 158.

${ }^{52}$ C. GIROIRE, Front Panel of a Sarcophagus Lid, in M. BEER - I. METJE - K. STRAUB (ed.), op. cit. (n. 42) p. 30-31.

53 Other analogies: an ivory plate from around 400 from Rome: L. Lopez: Decorative Plaque with the Nativity and the Adoration of the Magi, in: Ibidem 42-43.; two sarcophagi from the fifth century: VOLBACH 1952 109; an ivory pyxis from the turn of the fifth-sixth centuries from northern Italy: B. CHIESI, Pyxis with the Adoration of the Magi and the Annunciation to the Sheperds, in M. BEER - I. METJE - K. STRAUB (ed.), op. cit. (n. 42) p. 36-37, another sixth century ivory pyxis from the sixth century: N. HATOT: Pyxis with Sheperds and Angels, and the Adoration of the Magi, in Ibidem p. 38-39.;

${ }^{54}$ Sedulius: Carmen Paschale, Antwerp, Museum Plantin-Moretus, M 17.4, fol. 15v. The illumination is most likely a Carolingian copy of a late fifth century English original. C. LEWINE, The Miniatures of the Antwerp Sedulius Manuscript, The Early Christian Models and Their Transformations, I, PhD thesis at the Columbia University, 1970, 98-115. And recently: W. AUGUSTYN, Sedulius, Carmen Paschale (I) - Prosper of Aquitaine, Epigrammata (II), in: Ibidem p. 48-49. The composition also shows the same type as in Kostolany pod Tribečom. 
benchmark here: two of the kings are wearing a similar but shorter form of hat than what can be seen in Kostolany pod Tribečom - while the third king has a golden crown. ${ }^{55}$ As I see it, this particular detail, the hat of strange shape fits to the archaising tendency which occured in the eleventh-twelfth century. The wall paintings of the Sant'Urbano alla Caffarella Church (fig. 18) and of the Benedictine abbey of Lambach, and also Kostolany pod Tribečom attest that some artists still kept alive antique models, but formed them to the style of their own age and personality. ${ }^{56}$

\section{ARTISTIC EXCHANGE IN THE KOSTOL'ANY POD TRIBEČOM MURALS}

The obvious problem that we cannot find relevant analogies from the Hungarian kingdom and the whole central Europe for the iconographical solutions of the discussed murals of Kostol'any pod Tribečom cannot be explained only by the great loss of local material. ${ }^{57}$ The Annunciation, the Visitation, the Nativity, and the Magi images simply cannot be explained by local tradition. Instead of this, I have attempted to argue that all of these scenes are building on earlier models, mainly from late antiquity and the Carolingian era. These prototypes were meant to be old-fashioned, but not entirely forgotten in the eleventh-twelfth century, the time when the Kostolany pod Tribečom murals were made. Art pieces from the Mediterranaean served the role of preserving and then mediating certain iconographic types from late antique to Romanesque art.

If we should describe the iconographical program of the Kostolany church, a keyword would be their extreme archaism. However, this tendency was not entirely incidental. This offered us the chance to use the Kostolany pod Tribečom wall paintings to observe artistic exhange around the eleventh-twelfth century. From the analyzed examples we can see more clearly the starting points of these interrelations. However, most of the models stand apart in time and space quite distantly from the Kostolany pod Tribečom paintings. The most striking question of this study is how these models could possibly reach such a remote, isolated town in the northern mountains of the Hungarian kingdom, such as
Kostolany pod Tribečom? I do not suppose that their painter was such a travelled man who could have possibly seen the compelling monumental examples of these images, for instance the mosaics of the Italian peninsula or Byzantium. Objectively speaking the quality of these murals is far better than we would think from their actual state, but still under that of a high quality workshop with good standards. As I was trying to demonstrate, the iconographic, formal, and compositional similarities are so direct that it is not likely that the painter would have worked only according to an oral description of the landlord or the priest. Thus the master was primarily using visual sources. Even though from such a chronological distance we are not able to precisely define these, we can observe some possible mediators. Most probably the key elements here are small, and therefore mobile artefacts, such as ivories and manuscripts. I have attempted to analyze the iconographic origins of the highlighted scenes one by one, however, it is important that in many cases they were linked to each other. For instance, the enigmatic Salerno ivories from around 1100 contained a Visitation including the maidservant drawing away the curtain, and also a Magi cycle..$^{8}$ The Genoels-Elderen diptych presents a perfect example for the combination of the Annunciation and the Visitation, with both representing the same type as Kostolany pod Tribečom does. ${ }^{99}$ Beside these we have to consider the role of artistic manuals as possible visual sources as well.

Another key point of this research was to observe the personal attitude of the master to these models. As we have seen, in certain cases, for instance with the painting of the garments of the Magi it is obvious that he copied images that he did not entirely understand. This can be explained not through his insufficient artistic education, but rather with the vast distance of time that separated him from the prototypes. Still, the fact that he was copying and using these pictures implies that they still possessed power and were appealing to contemporary audiences. Therefore observing the iconography of the murals can shed light to artistic exhange between the Mediterranean world and the Hungarian kingdom, and also help to understand the complicated mechanisms of interchange when images moved across cultures and ages.

\footnotetext{
5 ZS. JÉKELY, Vizsoly, in ZS. JÉKELY - J. LÁNGI, Falfestészeti emlékek a középkori Magyarország északkeleti megyéiből, Budapest, 2009 , p. 430.

${ }^{56}$ The murals of the Sant'Urbano alla Caffarella were made about 1090: P. WILLIAMSON, op. cit. (n. 22), p. 224-228. The wall paintings in Lambach can be dated to before 1089: M. TÓTH, A kosztolányi templom falképei, op. cit. (n. 14), p. 64-66.

57 As I already emphasized, the paintings of Kostolany pod Tribečom is one of the earliest preserved wall painting cycle from the Hungarian kingdom, and also one of the most extended one from the Ârpád era (972-1301).

${ }^{58}$ The original form of the presentation of the so-called Salerno ivories is dubious. There are theories that they belonged to an altar, a throne, or a reliquary, etc., but all that is certain that it was dissolved before 1575; the scenes from the old and new testament, Apostles, donators and other decorative plates today scattered in many collections. S. DE MIERI, Per una fortuna critica degli avori di Salerno, in F. BOLOGNA (ed.), L' enigma degli avori medievali da Amalfi a Salerno, I, Pozzuoli, 2008, p. 99-131.

${ }^{59}$ See n. 21.
} 